\title{
DIVERS PERCEPTIONS AND IMPLICATIONS FOR SUSTAINABLE TOURISM MANAGEMENT IN THE GEARÁ STATE COAST, BRAZIL
}

\section{Percepção de mergulhadores e implicações para a gestão do turismo sustentável na costa do estado do Ceará, Brasil}

\author{
Ana Flávia Pantalena1, Marcelo de Oliveira Soares², Luís Miguel Campos Rodrigues³ \\ ${ }^{1}$ Pesquisadora, doutora, Instituto de Ciências do Mar (Labomar), Universidade Federal do Ceará. \\ E-mail: panta3@terra.com.br \\ 2 Professor, doutor, Instituto de Ciências do Mar (Labomar), Universidade Federal do Ceará. \\ E-mail: marcelosoares@ufc.br \\ ${ }^{3}$ Professor, doutor, Fundació ENT, Barcelona, Spain. E-mail: Icampos@ent.cat
}

\begin{abstract}
The analysis of the perceptions of divers can be a useful tool for developing sustainable tourism. Despite its importance, there is still little understanding of the role of perceptions of environmental and infrastructure problems in the improvement of diving tourism in developing countries. This study assesses the perceptions of 140 divers regarding different diving sites in the Ceará State Coast, northeastern Brazil. The results indicate that, despite the existence of 32 diving sites, only the Marine Protected Area (MPA) was regularly visited. This area was classified as "good/very good" in terms of its marine biodiversity. One of its particularities is the presence of reef environments. The divers gave the boats, and the operations of embarking and disembarking a "bad/poor" rating. Moreover, travel times and the presence of marine litter and abandoned fishing nets were considered as "reasonable/medium". Finally, this study discusses various strategies for preserving tropical marine biodiversity and maximizing the enjoyment of divers. These include the monitoring of illegal fishing, implementing the management plan of MPA, and improvements to the diving infrastructure. Understanding the preferences of recreational divers regarding dive experiences can strengthen sustainable tourism and be of great importance to the support of public policies and coastal management.
\end{abstract}

Keywords: diving tourism, coastal management, marine protected areas, coastal tourism.

Recebido em: 4/3/2019

Aprovado em: 22/10/2019

Publicado online em: 20/3/2020 


\section{RESUMO}

A análise das percepções dos mergulhadores pode ser uma ferramenta útil para o desenvolvimento do turismo sustentável. Apesar de sua importância, ainda há pouca compreensão do papel das percepções de problemas ambientais e de infraestrutura na melhoria do turismo de mergulho nos países em desenvolvimento. Este estudo avalia as percepções de 140 mergulhadores sobre diferentes locais de mergulho na costa do estado do Ceará, no Nordeste do Brasil. Os resultados indicam que, apesar da existência de 32 locais de mergulho, apenas a área marinha protegida (Parque Estadual Marinho Pedra da Risca do Meio) foi visitada regularmente. Essa área foi classificada como "boa/muito boa" no que diz respeito à biodiversidade marinha. Uma de suas particularidades é a presença de ambientes recifais. Os mergulhadores classificaram como "ruim/pobre" tanto as embarcações utilizadas como o embarque e desembarque para a prática do mergulho recreativo. Além disso, os tempos de viagem/navegação e a presença de lixo marinho e de redes de pesca abandonadas foram considerados "razoáveis/médios". Finalmente, este estudo discute várias estratégias de preservação da biodiversidade marinha tropical aliadas à satisfação e ao entretenimento dos mergulhadores, entre elas o monitoramento da pesca ilegal, a implementação do plano de gestão/ manejo da área marinha protegida e melhorias na infraestrutura utilizada na prática do mergulho. Compreender as preferências dos mergulhadores recreativos em relação às experiências de mergulho pode fortalecer o turismo sustentável, além de ser uma ferramenta de grande importância para o apoio das políticas públicas e da gestão costeira.

Palavras-chave: turismo de mergulho, gestão costeira, áreas marinhas protegidas, turismo costeiro.

\section{INTRODUCTION}

Studies on perception of public awareness have been adopted in environmental sciences with the goal of identifying any phenomenon or problem to be understanding and try forward solutions (Tang et al., 2013; Bennett \& Dearden, 2014a; Lim et al., 2015). Public perceptions research (PPR) (Jefferson et al., 2015) have been used in various coastal management studies to identify and characterize relevant phenomena and environmental problems (e.g., pollution, erosion, ecosystem services, climate change) (Lim et al., 2015; Mani-Peres et al., 2016). Such information can help to provide solutions to the identified problems affecting the development of sustainable diving tourism. For example, divers receive signals and stimuli from the social and physical marine habitats and use them to build up an understanding of that environment. The studies addressing the perception of divers focus on the conservation of species (Bramanti et al., 2011; Hunt et al., 2013; Smith et al., 2014; Shideler \& Pierce, 2016), the management of coral reefs (Brander et al., 2007; Camp \& Frazer, 2012; Lucrezi et al., 2013; Giglio et al., 2015) and the socioeconomic costs of climate change (Rodrigues et al., 2016).

The understanding of the perceptions of divers who have visited or regularly visit diving locations near coastal cities is important for ensuring the sustainable development of marine ecotourism. These studies can support governments and tourism managers in the implementation of policies that reduce the impact of tourism on marine and coastal ecosystems (Brander et al., 2007; Tonin \& Lucaroni, 2017). This type of policies benefits the society, including income for fishing communities and diving schools, as well as improving 
leisure quality and environmental awareness for visitors (Asafu-Adjaye \& Tapsuwan, 2008; Bennett \& Dearden, 2014a; Mundet Ribera, 2001). The knowledge about the perceptions of divers may contribute for the promotion of sustainable tourism management. This is mainly due to the fact that perception analysis addresses the specificities of the relationship between society and environment, including how these may be affect positively or negatively as a result of different ecosystem management approaches (Debrot \& Nagelkerken, 2000; Andrade \& Soares, 2017).

Recreational scuba diving and snorkeling are adventure sports that focuses on the marine environment. This type of tourism has grown in recent years in many developing countries, including Thailand (Asafu-Adjaye \& Tapsuwan, 2008), Fiji (Fitzsimmons, 2008); South Africa (Lucrezi et al., 2013), and Brazil (Giglio et al., 2015, Rhormens et al., 2017). The richness of its seascape and marine biodiversity makes it appealing to scuba divers. There are approximately 65 thousand divers in Brazil, and 15 thousand new SCUBA diving certifications are accredited every year. Moreover, this activity is responsible for an annual input of US\$ 3 million in the dive equipment market and approximately US\$ 7 million in the travel and tourism sectors (Wegner \& Tonioli, 2006; Padi, 2011; Pires et al., 2016). The increased interest in ecotourism, coupled with the availability of more reliable and affordable modern diving and underwater photographic equipment, have contributed substantially to making this activity popular in many developing countries (Asafu-Adjaye \& Tapsuwan, 2008; Fitzsimmons, 2008; Lucrezi et al., 2013).

During the study there were three recreational diving schools in Fortaleza, which, in addition to accreditation of new students for the practice of the activity, also provide courses on dive specialties (e.g. "Fotosub", advanced Dive, NITROX, shipwreck). They provide also: cylinder recharge, sale of equipment and organize meetings of divers and dive trips to many of the dive points in Ceará and other States and to international dive sites.

According to instructors/owners of those diving schools, they would have accredited approximately 4,700 students in the last ten years, between basic course (Open water scuba dive), advanced diving course and specialties, with an average of 450 to 470 students per year. According to Padi Brazil (Padi, 2011), Ceará is in the 14th place among States with the highest number of accredited students.

This study aims to evaluate the perceptions of recreational divers in Brazilian waters (Fortaleza, Brazil), and assesses the strengths and weaknesses of diving tourism in these tropical areas. Accordingly, this study aims to contribute to the improvement of knowledge about the perceptions of divers and its application.

\section{MATERIALS AND METHODS}

\section{Study site}

The city of Fortaleza (capital of the state of Ceará) is located on the Northeast (NE) coast of Brazil. Fortaleza's population has expanded in recent decades to approximately 2.6 million, with a population of more than 3.5 million in the greater metropolitan region. Fortaleza is a well-established beach destination and one of largest vacation attractions on the Tropical Coast of Brazil (Oliveira, 2003; Garmany, 2011). Fortaleza is a popular national and international destination for tourists interested in beautiful landscapes, seascapes, and leisure. Natural attractions such as lagoons, dunes, and beaches attract tourists to visit the 
city (Oliveira, 2003). In addition, it is possible to find sandstone reefs (Soares et al., 2016) in the surrounding coastal area, shipwrecks, and tropical marine biodiversity, which add up to the number and variety of nature tourism attractions available to visitors (Andrade \& Soares, 2017).

The study site (Figure 1) includes 32 diving sites within $10 \mathrm{~km}$ to $31 \mathrm{~km}$ from Fortaleza and the Marine Protected Area (MPA) of "Parque Estadual Marinho da Pedra da Risca do Meio" (PEMPRM), which is located $12 \mathrm{Km}$ northeast of Fortaleza. PEMPRM is the only totally underwater marine protected area in the state of Ceará, and one of a few offshore MPAs in the Tropical Southwestern Atlantic. It covers an area of $33.20 \mathrm{~km}^{2}$. This rectangular MPA shelters submerged reefs between 14 and 28 meters deep and tropical marine biodiversity, which provide a variety of nature tourism attractions for visitors (Supplementary information II). Civil society organizations mobilized to create this site in order to meet the following objectives: protecting the marine habitat and ensuring that native species can feed and reproduce; developing sustainable artisanal fishery programs; and encouraging underwater tourism, while also raising awareness about the need to guarantee the sustainability of the aquatic resources of the MPA (Andrade \& Soares, 2017; Freitas \& Lotufo, 2015).

Figure 1 - Study site - Map of common recreational diving sites around the coast of Fortaleza (NE, Brazil). Please see the names of the diving sites in Supplementary Material I

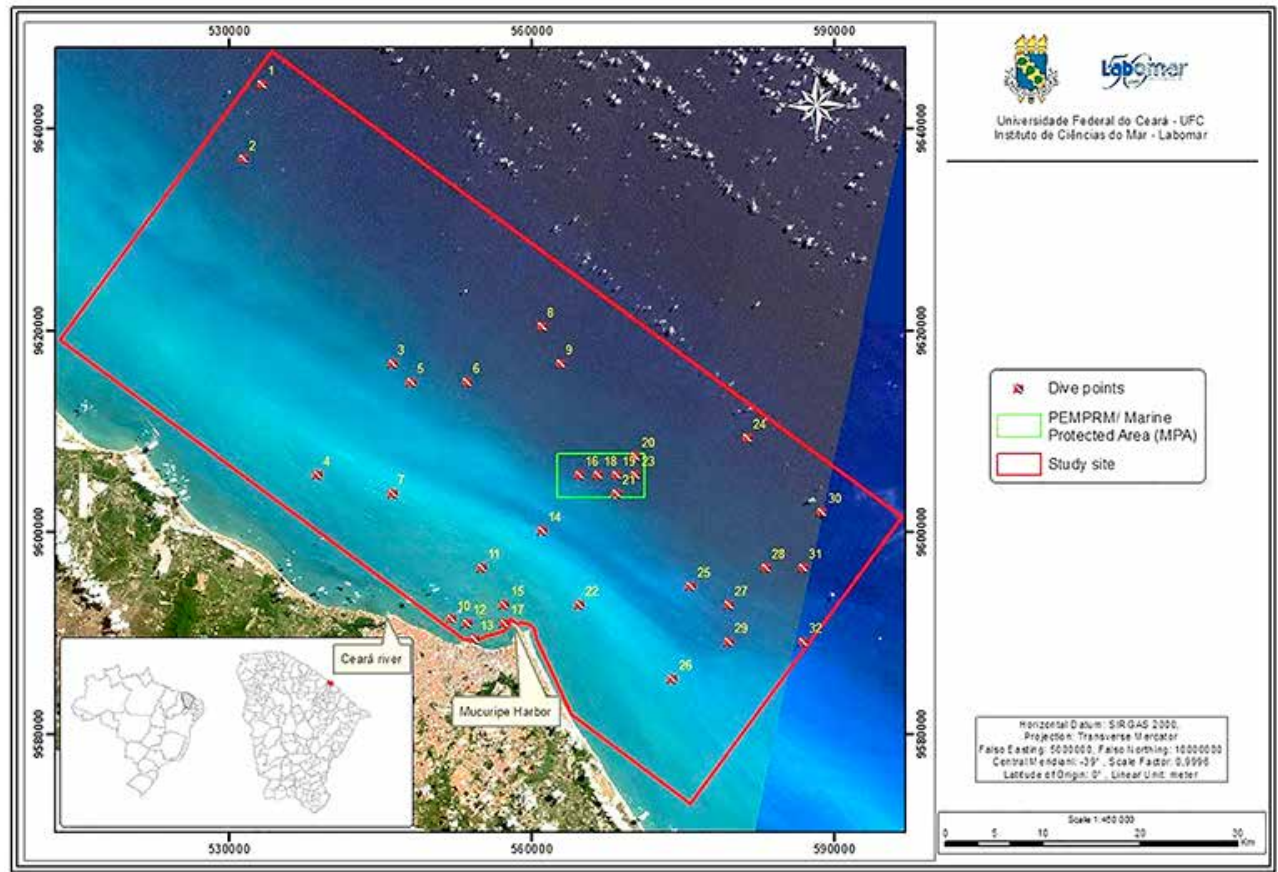

Recent studies have shown that 207 reef fish species can be found on the Ceará coast (Pinheiro at al., 2018), and 131 fish species in the PEMPRM (Freitas et al., 2019). Thirteen of these species $(10 \%)$ are mentioned in categories with some level of threat at the IUCN (IUCN, 2019) or in the Brazilian red list categories and six are considered endemic to the Brazilian biogeographic province (Soares et al., 2011; Freitas et al., 2019). Examples include the Atlantic goliath grouper (Epinephelus itajara), Queen Angel Fish (Holacanthus ciliaris), Nurse shark (Ginglymostoma cirratum), and the Spiny lobster 
(Panulirus meripurpuratus) and Smoothtail Spiny Lobster (Panulirus laevicauda) (Freitas \& Lotufo, 2015; Andrade \& Soares, 2017).

\section{Data collection and analysis}

Perceptions among recreational divers were surveyed through structured questionnaires. The questionnaires included open (qualitative) and closed questions (see supplementary information III). The data was processed by free statistical software (Graph Pad Instat 3.06, Graph Pad Statmate and PAST (Hammer, 2001)). Questionnaires were structured and elaborated using similar methodology of previous studies aiming at investigating divers' perceptions about various characteristics of the diving sites (AsafuAdjaye \& Tapsuwan, 2008; Giglio et al., 2015; Hannak et al., 2011; Kirkbride-Smith et al., 2013). These included marine biodiversity, environmental problems (e.g., marine litter and abandoned fishing gears), and infrastructure of scuba diving activities. To analyze the perception of divers, this study adopted the concepts and theoretical framework provide by Sudarmadi et al. (2001).

The preferences of tourists regarding diving experiences can be influenced by various factors, including: 1) marine ecosystems aspects (e.g., marine life abundance, visibility, water temperature);2) aspects related to the service of dive operators and management of MPAs (e.g., safety, boats; embarking/disembarking); and 3) characteristics associated with cruising time to dive locations. The survey collected information from divers about various issues related to diving logistics, such as boats, docking and boarding facilities, support structures, and their general perception of diving site features (coral reefs and shipwrecks) (Uyarra et al., 2009; Rodrigues et al., 2016).

The questionnaire consisted of a total of 20 questions, divided in 18 questions of multiple choice, and two open ended questions which the answers were grouped according the similarity of the answers ${ }^{1}$. The questions were divided into three major sections: the first group assessed the sociodemographic profile of the divers (e.g., gender, age, profession, scuba certification level); the second group focused on the assessment of various characteristics of the offshore MPA (Parque Estadual da Pedra da Risca do Meio) by the divers (e.g., biodiversity, seascape, and environmental impact); and the third one evaluated the logistics of existing diving operations, including ships and docking. The question regarding the "Places you've dived in the state" could have more than one answer per person, each choice was considered separately as single answer. For the question "best dive site in the state" (open answer) the answers were grouped in MPA and Shipwrecks.

The questionnaires were distributed to scuba divers through diving clubs, dive centers and dive schools via digital mode (by email, social media and online survey development cloud). The combination of two sampling techniques was used to recruit participants: targeted sampling (i.e. deliberate targeting of divers) and snowball sampling. The survey mode (using digital mode) to distribute the self-administered questionnaires has scientific validity and is a common approach (Lim et al., 2015).

The questionnaires respected the anonymity of respondents, and researchers had access to the answers provided by each respondent without their personal identification. The study counted with a random sample of 140 divers providing valid answers.

\footnotetext{
${ }^{1}$ Occupations were classified and grouped in accordance with the classification system of the Brazilian Institute of Geography and Statistics following. Source: http://www.mtecbo.gov.br/cbosite/pages/home.jsf. Accessed in: Jan. 2016.
} 
Considering a confidence level of $95 \%$, the sample used in this study stayed above the required sample size of 139 valid answers and are comparable with other studies (Camp \& Fraser, 2012; Chung et al., 2013; Smith et al., 2014). The questionnaire has been tested for a period of two days (pilot) prior to distribution (June 2015) to identify any ambiguous questions and/or responses to improve the clarity and understanding of the questionnaire. The answers to the structured questionnaire were statistically analyzed using the chisquared test $\left(X^{2}\right)$ at a significance level of $5 \%$. Raw data were also converted into relative data, to obtain the classes' relative distributions. The answers presented by the participants were categorized, and frequencies were defined for each answer category. It is worth noting that each participant could present multiple answers to some questions. In such cases, the sum of the generated frequencies was above $100 \%$. The results are presented using percentages (\%) and the chi-square analysis, which is a form that was considered enough for analysis (Andrade \& Soares, 2017).

\section{RESULTS}

\section{Socioeconomic aspects, diving frequency and characterization}

The majority of respondents were men (72\%) between the ages of 31 and 40 . Regarding the respondents' occupations, it was observed a significant representation of science and arts professionals (44.3\%) while $18.6 \%$ had occupations in the production of goods and industrial services, and $17.1 \%$ identified as being company directors, managers or entrepreneurs, while the remainder were employed in the public/military services $(7.9 \%)$ various other occupations $(7.9 \%)$, and in the service/retail sector $(4.3 \%)$. In terms of their dive experience, $50 \%$ of respondents had dived more than 5 times, followed by $21.4 \%$ who had dived between 1 and 2 times in this coast. Most divers $(48.6 \%)\left(\chi^{2}, \mathrm{P}=\right.$ $0.005)$ had been diving in recent years (less than 1 year) followed by $1-3$ years $(20 \%)$.

The shore dives $(83.6 \%)$, MPA $(78.4 \%)$, and the shipwrecks $(78.4 \%)$ were pointed as the most visited diving sites; of these, the MPA was chosen as the best diving site $(49 \%)$, followed by the shipwrecks (39\%). The category "Others" include the shore dives and the diving sites outside the MPA. However, the statistical analysis $\left(\chi^{2}, \mathrm{P}=\right.$ 0.48) indicate any significant difference between the MPA and the shipwrecks. A significant percentage of divers prefer to dive in the MPA and shipwrecks instead of the remaining sites.

\section{Environmental characteristics, impacts and diving infrastructure}

The MPA received the highest score $\left(\chi^{2}, \mathrm{P}<0.001\right)$ for marine biodiversity, being rated as "good/very good". The seascape and underwater visibility were the attributes mostly classified "medium/reasonable" (Table I). The same classification was given to time needed to travel to diving activities also to marine litter, and abandoned fishing lines (ghost nets) $\left(\chi^{2}, \mathrm{P}=0.03\right)$.

The boats and facilities for embarking/disembarking were significantly classified by most divers (45.7\% and $42.1 \%$ respectively) as "bad/poor" $\left(\chi^{2}, \mathrm{P}=0.004\right)$. This result demonstrates the diver's perceptions about 'Quality and comfort provided by the dive services' (Table I). 
Table I - Divers perception about MPA dive sites, environmental impacts and diving infrastructure

\begin{tabular}{lccc}
\hline \multicolumn{1}{c}{ Characteristic } & $\begin{array}{c}\text { Good/Very good } \\
\mathbf{( \% )}\end{array}$ & $\begin{array}{c}\text { Medium/Reasonable } \\
\mathbf{( \% )}\end{array}$ & $\begin{array}{c}\text { Bad / Poor } \\
\mathbf{( \% )}\end{array}$ \\
\hline Marine biodiversity & 52,6 & 43,9 & 3,5 \\
\hline Seascape & 40,5 & 54,1 & 5,4 \\
\hline Visibility & 41,4 & 53,2 & 5,4 \\
\hline Crusing time & 9 & 45,9 & 45 \\
\hline $\begin{array}{l}\text { Marine litter and } \\
\text { abandoned fishing nets } \\
\text { (ghost nets) }\end{array}$ & 22,3 & 49,1 & 28,6 \\
\hline Quality of dive boat & 22,9 & 31,4 & 45,7 \\
\hline Embark/desembark & 26,4 & 31,4 & 42,1 \\
\hline
\end{tabular}

\section{Incentives to diving}

Divers were asked about which incentives would encourage them to dive more frequently in Fortaleza. Results indicate that service improvements $(21.1 \%$ of the respondents), and the creation of new diving sites (e.g., new natural sites, creation of artificial reefs, underwater trails) $(20.7 \%)$ were chosen as the preferable incentives by the divers. Other types of incentives well rated by the respondents included more attractive prices $(17.4 \%)$, and more widely disseminated information about diving sites (16\%) (Figure 2).

Figure 2 - Incentives for diving more frequently on the Fortaleza coast (NE, Brazil)

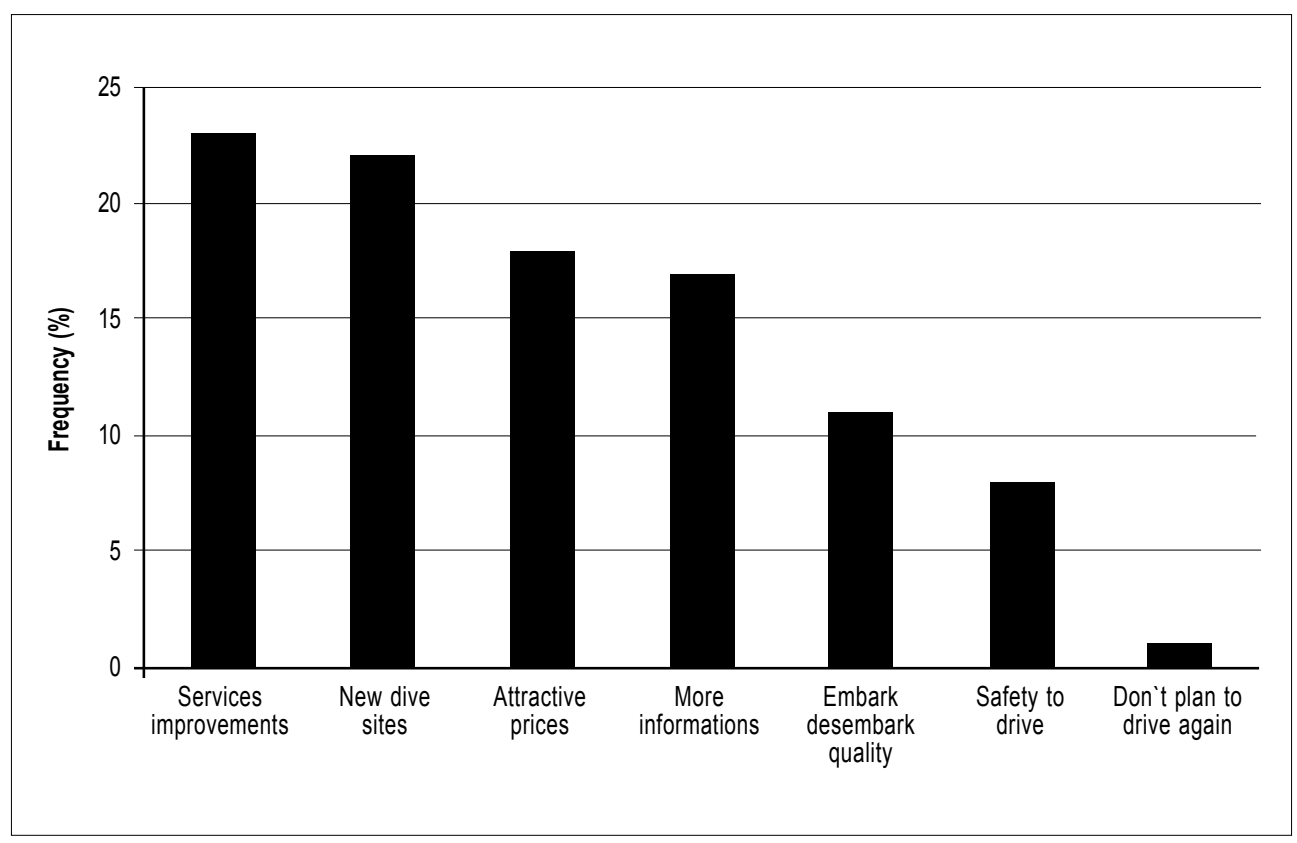

\section{DISCUSSION}

This study provides findings that may support the development of marine sustainable tourism in Ceará State Coast. First, divers can provide information about the strengths and weaknesses of the diving infrastructure, as well as and the threats affecting the marine 
biodiversity. Second, to improve diving tourism, it is necessary to implement policies aiming at developing the diving infrastructure (e.g., boats and facilities for embarking and disembarking operations), reducing the anthropogenic impacts (e.g., marine litter and ghost nets), and creating new diving sites to guarantee the regular offer of diving opportunities.

\section{Perceptions of divers}

The study area presents good conditions for the development of recreation and tourism activities. These includes good weather conditions year round; sea surface temperatures of $27-29{ }^{\circ} \mathrm{C}$; a significant number of hotels; and a rich tropical marine biodiversity. Nevertheless, diving tourism is not so developed in comparison with other areas in the Brazilian coast (Giglio et al., 2015; Pires et al., 2016), and other world regions such as the Caribbean Sea (Green \& Donnelly, 2003).

The results indicate that the offshore MPA is the preferred diving destination for most of the respondents. Their environmental perception of the diversity of species was rated as "good/very good." This attractive feature can persuade tourists to choose the MPA as their diving destination. This finding is relevant because it can be used to improve the scuba diving program, as well to indicate future environmental protection alternatives. MPAs are important for the protection of tropical marine ecosystems, supporting the conservation of coral reefs and contributing to the maintenance of sustainable fishing. Moreover, MPAs enable scientific research and may promote recreational diving as a form of sustainable tourism, the latter benefiting the local economy (Asafu-Adjaye \& Tapsuwan, 2008; Giglio et al., 2015; Lucrezi et al., 2013).

The major attractions of a diving destination are the abundance and diversity of fish, and the condition of the coral cover (Fitzsimmons, 2008; Kirkbride-Smith et al., 2013; Mundet \& Ribera, 2001; Schuhmann \& Casey, 2013; Uyarra et al., 2009). Attractive species for recreation and research purposes include sharks, rays, lobsters, turtles, fish, and invertebrate species. The practice of scuba diving in the MPA benefits from the rich marine biodiversity. The average depth is 25 meters, with predominantly sandy floors featuring gravel, tropical reefs, and a high incidence of calcareous algae (Freitas \& Lotufo, 2015; Soares et al., 2016).

The potential creation of new diving sites (e.g., artificial reefs and shipwrecks) was considered as positive for a significant proportion (21\%) of the divers in this study (Figure 2). This measure was applied in the coastal waters of other countries, including the US, Barbados, Canada, South Africa, and New Zealand, where submerged structures of different origins, morphology, complexity, and composition, were used to enhance fish stocks and other marine life, benefitting recreational activities and fisheries (Jakšić et al., 2013; Kirkbride-Smith et al., 2013; Schuhmann \& Casey, 2013).

In addition, $30 \%$ of the respondents selected the infrastructure and service quality as a motivation to dive more or return to dive. The poor quality of the areas used for embarking/disembarking and of some services, particularly those relating to infrastructure of boats and the cruising time to reach the MPA ( 2 hours), were the main factors discouraging respondents from diving. Better prices $(17.4 \%)$ and more information about diving activities in the city $(16 \%)$ were also relevant for respondents. The decision to book a diving vacation relies on many considerations, including the availability of accommodation, marine conservation, diving operations, prices and diving staff (Fitzsimmons, 2008; Mundet \& 
Ribera, 2001; Peters \& Hawkins, 2009; Uyarra et al., 2009). Results suggest that not only marine life diversity found in the MPA contributes for scuba diving enjoyment. Other factors include, inter alia, the diving operation, docking, equipment, and available services. This suggests that more investment in infrastructure by the local government and diving industry could maximize the divers' enjoyment and increase diving tourism along the coast, attracting not only the local diving community but also tourists visiting the state for other reasons, such conferences and beach tourism.

By enabling a better understanding of the motivations and preferences of divers, this study can help diving operators and MPA managers to improve the diving conditions. Also, in addition, it may serve as an important tool for attracting the attention of divers and satisfying their expectations, with evident benefits for the diving tourism and coastal communities.

\section{Opportunities for the development of sustainable diving tourism}

Good weather conditions, diving infrastructure, environmental features are among some of the most important factors for tourists choosing tropical holiday destinations, greatly contributing to their enjoyment (Fitzsimmons, 2008; Mercado \& Lassoire, 2002; Mundet \& Ribera, 2001; Uyarra et al., 2009).

According to the results, underwater visibility was one of the environmental characteristics evaluated as "medium/reasonable." The perception of underwater visibility can be explained by environmental conditions. The study site is strongly affected by highspeed winds and swell events (Sauermann et al., 2003; Tsoar et al., 2009), which generate turbidity and, consequently, medium visibility at certain periods, particularly during the second semester August-December). The underwater visibility of the NE Brazilian coast is generally caused by high-energy sedimentary fluxes, oligotrophic waters, and strong hydrodynamic processes (Gomes et al., 2014; Teixeira \& Machado, 2013).

Another element rated as "medium/reasonable" was the seascape. Large expanses of carbonate sediments (sand) (Leão \& Dominguez, 2000) and the absence of true coral reefs (more common in eastern Brazil) (Leão et al., 2016) may explain this rating. Nevertheless, divers were attracted to the MPA's tropical sandstone reefs, which have the richest marine life (Soares et al., 2016), may be the reason the MPA was rated as the best dive site for $49 \%$ of the divers. The previous two environmental conditions are particularly important determinants of diving site enjoyment, together with features such as the fish diversity (evaluated as good/very good) related to the presence of reefs in the MPA.

Respondents judged boat comfort, embarking/ disembarking facilities, cruising time, and the presence of garbage/abandoned fishing lines in the diving sites as "reasonable/ poor." Diving schools use rented vessels to access the MPA, which includes most of the main diving sites available for training and marine tourism. Tourists embark and equipment is unloaded into the Fortaleza beach by means of small wood rafts, which come out to the main vessel and transport people and equipment. The cruising time for most diving sites in the MPA is about $1 \mathrm{~h} 30 \mathrm{~m}$ to $2 \mathrm{~h}$, and it can reach the maximum of $4 \mathrm{~h}$ to get the farthest points, outside the MPA. The long cruising times and sea conditions may discourage tourists wishing to avoid seasickness and hot weather.

Without investment and management interventions, the negative perceptions of tourists could influence their future diving and vacation decisions (Fitzsimmons, 2008; Mundet \& Ribera, 2001; Uyarra et al., 2009). Recreational diving is not just a sport or a 
sightseeing activity, but also an important tool for involving visitors with the issue of sustainable marine development. It is important to promote the tangible and intangible benefits resulting from the conservation of the marine environment (Bramanti et al., 2011; Hunt et al., 2013; Lucrezi et al., 2017).

\section{Recommendations and proposed actions for sustainable tourism}

The results reveal a high level of satisfaction among divers with the diving sites and marine life of the MPA, and some dissatisfaction with the environmental problems, diving services and infrastructure provided. The level of enjoyment that divers experience is an important factor, which must influence future conservation and sustainable tourism policies. Divers can also be encouraged to engage in more responsible behavior on their next dives, support biological conservation programs, or agree to pay an MPA fee to conserve the marine environment.

Several studies (Fitzsimmons, 2008; Green \& Donnelly, 2003; Heyman et al., 2010; Lucrezi et al., 2013; Mundet \& Ribera, 2001; Peters \& Hawkins, 2009; Schuhmann \& Casey, 2013; Shideler \& Pierce, 2016; Uyarra et al., 2009 b) suggest that scuba divers have a clear appreciation of, and willingness to pay for, higher levels of marine quality, fish and coral diversity and sightings of large animals (e.g., rays, goliath groupers, sharks, and whales). The law that created the MPA in Fortaleza (Brazil) considers the possibility of a fee to be charged to users to support its management. Nevertheless, it was never implemented. The lack of surveillance and environmental monitoring made it difficult for the government to effectively protect the MPA (Soares et al., 2016). Charging a fee could make an important contribution towards the maintenance of the MPA. Moreover, this financial support could be used to develop a partnership with artisanal fishing communities and to raise the coastal community's awareness of the socioeconomic and environmental relevance of the MPA.

Effective marine protection and sustainable scuba diving tourism rely on the conservative use of natural resources. It is also important for community to feel some responsibility for conserving and protecting the MPA for future use. The degradation of a diving destination, through the loss of coral cover in tropical reefs and a reduction in marine life, can have significant detrimental effects on the local diving industry and the economy of a coastal community (Asafu-Adjaye \& Tapsuwan, 2008; Brander et al., 2007; Fitzsimmons, 2008; Mundet \& Ribera, 2001).

To increase the enjoyment of divers and to motivate the diving industry, the findings of this study suggest a possible increase in environmental management measures to monitor and eliminate illegal fishing boats in the MPA, as well as the establishment of partnerships with local artisanal fishing communities, diving schools and the Government to enforce this initiative (Asafu-Adjaye \& Tapsuwan, 2008; Craig, 2008; Giglio et al., 2011; Ku \& Chen, 2013).

Regardless of the controversial aspects of the creation of artificial reefs in the near area of natural reefs, due to the attraction that artificial reefs exert over large demersal predators can negatively affect nearby natural areas through shifts in predation, competition or nutrient input (Simons et al., 2011). This study revealed the interest of local divers in the creation of new diving sites using artificial reefs and underwater trails (Rhormens et al., 2017) and shipwrecks closer to the coast, allowing to reduce cruising times, and taking advantage of a good water visibility during some periods of the year. These structures 
could be used to attract marine life, improve diving tourism, and provide buoyancy training for novice divers (Jakšić et al., 2013; Worachananant et al., 2008).

The enforcement in the use of boat moorings in the MPA to avoid damage to the substrate, as well as the establishment of pre-dive briefing sessions (Giglio et al., 2015) that offer clear information about avoiding contact with marine life are additional recommendations. These are marine environmental protection practices that should be part of the standard procedures for diving schools (Chung et al., 2013; Lynch et al., 2013; Worachananant et al., 2008).

Recent studies suggest cases where underwater tourism activity, despite of providing viable economic opportunities for local communities, it can be responsible for environmental impacts, stress on marine life and modifying species behaviour/ physiology as well as habitat use (Benevides et al., 2019). The present study reinforces the importance of future research of the load capacity (number of dives per dive site/per day) of the MPA, the damage of the overexploited visitation and its importance could be currently underestimated.

Finally, the government should advertise scuba diving activities to promote sustainable diving tourism. It is necessary to draw attention to the existence of the MPA, and to educate people about the need to conserve it for the community, for scientific research, and as a diving destination for tourists and local community.

\section{CONCLUSIONS}

In conclusion, the results indicate that the MPA is one of the best and most visited diving sites, benefiting from its rich marine biodiversity and the presence of tropical coral reefs. Nevertheless, the quality of some services, cruising times, and the evidence of anthropogenic impacts (e.g., the presence of marine litter and abandoned fishing lines) are not so appreciated by recreational divers. The improvement in the quality of the services, the creation of new and more widespread diving sites, as well as the possibility to offer lower prices, may represent an incentive for tourists interested in scuba diving.

The divers perceptions is a useful source of information for developing public policies focused on the promotion of environmental education and sustainable diving tourism. Moreover, it benefits marine biodiversity conservation and the stakeholders directly or indirectly involved with the tourism sector (Fitzsimmons, 2008; Lucrezi et al., 2013; Uyarra et al., 2009). This is important because it reveals the interrelationships between tourists and the marine environment, including the preferences of divers regarding characteristics of the diving sites, inter alia, the type of seascape and marine biodiversity. The results may be applied and adapted for other developing countries (Andrade \& Soares, 2017; AsafuAdjaye \& Tapsuwan, 2008; Mani Peres et al., 2016).

This study considers the importance of public policies to improve the sustainable tourism management in developing countries. The main findings of this study may be useful to similar cases in other developing countries.

Recreational scuba diving is an activity that can encourage sustainable tourism, promote socioeconomic development, and serve as a tool for environmental education and awareness as it encourages tourists to engage with the marine environment. To promote responsible diving and prevent any negative anthropogenic impact on the biodiversity, requires adequate measures to supervise and protect natural resources and their sustainable use for future generations. 
Acknowledgments - The authors would like to thank the financial support granted by FUNCAP (Fundação Cearense de Desenvolvimento Científico e Tecnológico do Ceará). We also would like to thank the diving schools of Ceará state, who made this work possible. We wish to acknowledge the editor and two anonymous referees for comments provided on the manuscript, which significantly improved this manuscript.

Conflict of interest: the authors declare that they have no conflict of interest.

Ethical approval: "All procedures performed in studies involving human participants were in accordance with the ethical standards of the institutional and/or national research committee and with the 1964 Helsinki declaration and its later amendments or comparable ethical standards."

Informed consent: "Informed consent was obtained from all individual participants included in the study."

\section{BIBLIOGRAPHIC REFERENCES}

Asafu-Adjaye J. \& Tapsuwan, S. A contingent valuation study of scuba diving benefits: case study in Mu Ko Similan Marine National Park, Thailand. Tourism Management, v. 29, p. 1122-1130, 2008. doi: 10.1016/j.tourman.2008.02.005.

Andrade, A.B. \& Soares, M.O. Offshore marine protected areas: divergent perceptions of divers and artisanal fishers. Marine Policy, v. 76, p.107-113, 2017. doi: 10.1016/j. marpol.2016.11.016.

Benevides, L.J.; Cardozo-Ferreira, G.C.; Ferreira, C.E.L.; Pereira, P.H.C.; Pinto, T.K. \& Sampaio, C.L.S. Fear-induced behavioural modifications in damselfishes can be divertriggered. Journal of Experimental Marine Biology and Ecology, v. 514-515, p. 34-40, 2019.

Bennett, N.J. \& Dearden, P. Why local people do not support conservation: Community perceptions of marine protected area livelihood impacts, governance and management in Thailand. Marine Policy, v. 44, p. 107-116, 2014a. doi: 10.1016/j.marpol.2013.08.017.

Bennett, N.J. \& Dearden, P. From measuring outcomes to providing inputs: governance, management, and local development for more effective marine protected areas. Marine Policy, v. 50, n. 96-110, 2014b. doi: 10.1016/j.marpol.2014.05.005.

Bramanti, L.; Vielmini, I.; Rossi, S.; Stolfa, S. \& Santangelo, G. Involvement of recreational scuba divers in emblematic species monitoring: the case of Mediterranean red coral (Corallium rubrum). Journal for Nature Conservation, v. 19, p.312-318, 2011. doi:10.1016/j. jnc.2011.05.004.

Brander, L.M.; Van Beukering, P. \& Cesar, H.S.J. The recreational value of coral reefs: a meta-analysis.EcologicalEconomics, v.63,p.209-218,2007.doi:10.1016/j.ecolecon.2006.11.002.

Camp, E. \& Fraser, D. Influence of conservation education dive briefings as a management tool on the timing and nature of recreational SCUBA diving impacts on coral reefs. Ocean $\mathcal{E}$ Coastal Management, v. 61, p. 30-37, 2012. doi: 10.1016/j.ocecoaman.2012.02.002.

Chung, S.-S.; Au, A. \& Qiu, J.-W. Understanding the underwater behaviour of scuba divers in Hong Kong. Environmental Management, v. 51, p. 824-37, 2013. doi: 10.1007/s00267-013-0023-y. 
Craig, R.K. Fishers, divers, scientists, lawyers, and marine protected areas: the US experience in protecting coral reefs. Tourism in Marine Environments, v. 5, p. 89-99, 2008. doi: $10.3727 / 154427308787716721$.

Debrot A.O. \& Nagelkerken, I. User perceptions on coastal resourse state and management options in Curacao. Revista de Biologia Tropical, v. 12, 2000.

Fitzsimmons, C. Why dive? and why here? a study of recreational diver enjoyment at a fijian eco-tourist resort. Tourism in Marine Environments, v. 5, n. 2-3, p. 159-173, 2008. doi: DOI: $10.3727 / 154427308787716785$.

Freitas, J.E.P. \& Lotufo, T.M.C. Reef fish assemblage and zoogeographic affinities of a scarcely known region of the western equatorial Atlantic. Journal of the Marine Biological Association of the United Kingdom, v. 95, p. 623-633, 2015. doi: 10.1017/S0025315414001404.

Freitas, J.E.P.; Araújo, M.E. \& Lotufo, T.M.C. Composition and structure of the ichthyofauna in a marine protected area in the Western 9, J. W. D. P. The interplay between structural inheritance and morphology in the Equatorial Continental Shelf of Brazil. Marine Geology, v. 355, p. 150-161, 2014. doi: 10.1016/j.margeo.2014.06.002.

Green, E. \& Donnelly, R. Recreational scuba diving in Caribbean marine protected areas: do the users pay? AMBIO: a Journal of the Human Environment, v. 32, p. 140-144, 2003. doi: 10.1579/0044-7447-32.2.140.

Hannak, J.S.; Kompatscher, S.; Stachowitsch, M. \& Herler, J. Snorkelling and trampling in shallow-water fringing reefs: risk assessment and proposed management strategy. Journal of Environmental Management, v. 92, p. 2723-2733, 2011. doi: 10.1016/j.jenvman.2011.06.012.

Hammer, Ø.; Harper, D.A.T.; Ryan, P.D. PAST: paleontological statistics software package for education and data analysis. Palaeontologia Electronica, v. 4, n. 1, 9 p., 2001. http:// palaeo-electronica.org/2001_1/past/issue1_01.htm.

Heyman, W.D.; Carr, L.M. \& Lobel, P.S. Diver ecotourism and disturbance to reef fish spawning aggregations: it is better to be disturbed than to be dead. Marine Ecology Progress Series, v. 419, p. 201-210, 2010. doi: 10.3354/meps08831.

Hunt, C.V.; Harvey, J.J.; Miller, A.; Johnson, V. \& Phongsuwan, N. The green fins approach for monitoring and promoting environmentally sustainable scuba diving operations in South EastAsia.Ocean ECoastalManagement, v.78,p.35-44,2013.doi:10.1016/j.ocecoaman.2013.03.004.

IUCN. The IUCN Red List of Threatened Species. Version 2019-2. 2019. http://www. iucnredlist.org. Downloaded on: 16 Sept. 2019.

Jakšić, S.; Stamenković, I. \& Đorđević. J. Impacts of artificial reefs and diving tourism. International Scientific Journal Turizam, v. 17, p. 155-165, 2013.

Jefferson, R.; McKinley, E.; Capstick,S.; Fletcher,S.; Griffin,H. \&Milanese, M. Understanding audiences: making public perceptions research matter to marine conservation. Ocean $\mathcal{E}$ Coastal Management, v. 115, p. 61-70, 2015. doi: 10.1016/j.ocecoaman.2015.06.014.

Kirkbride-Smith, A.E.; Wheeler, P.M. \& Johnson, M.L. The relationship between diver experience levels and perceptions of attractiveness of artificial reefs - examination of a potentialmanagement tool. PLoS One, v. 8, p.68899,2013. doi:10.1371/journal.pone.0068899.

$\mathrm{Ku}$, K.C. \& Chen, T.C. A conceptual process-based reference model for collaboratively managing recreational scuba diving in Kenting National Park. Marine Policy, v. 39, p. 1-10, 2013. doi: 10.1016/j.marpol.2012.09.008. 
Leão, Z.M.A.N. \& Dominguez, J.M.L. Tropical coast of Brazil. Marine Pollution, v. 41, p. 112-122, 2000. doi: 10.1016/S0025-326X(00)00105-3.

Leão, Z.M.A.N.; Kikuchi, R.K.P.; Ferreira, B.P.; Neves, E.G.; Sovierzoski, H.H.; Oliveira, M.D.M.; Maida, M.; Correia, M.D. \& Johnsson, R. Brazilian coral reefs in a period of global change: a synthesis. Brazilian Journal of Oceanography, v. 64, p 97-116, 2016. doi: 10.1590/ S1679-875920160916064sp2.

Lim, S.S.; Innes, J.L. \& Meitner, M. Public awareness of aesthetic and other forest values associated with sustainable forest management: a cross-cultural comparison among the public in four countries. Journal of Environmental Management, v. 150, p. 243-249, 2015. doi: 10.1016/j.jenvman.2014.11.026.

Lucrezi, S.; Milanese, M.; Markantonatou, V.; Cerrano, C.; Sarà, A.; Palma, M. \& Saayman, M. Scuba diving tourism systems and sustainability: perceptions by the scuba diving industry in two Marine Protected Areas. Tourism Management, v. 59, p. 385-403, 2017. doi: 10.1016/j.tourman.2016.09.004.

Lucrezi, S.; Saayman, M. \& Merwe van der, P. Managing diving impacts on reef ecosystems: analysis of putative influences of motivations, marine life preferences and experience on divers' environmental perceptions. Ocean $\mathcal{E}$ Coastal Management, v. 76, p. 52-63, 2013. doi: 10.1016/j.ocecoaman.2013.02.020.

Lynch, T.P.; Harcourt, R.; Edgar, G. \& Barrett, N. Conservation of the critically endangered eastern Australian population of the grey nurse shark (Carcharias taurus) through crossjurisdictional management of a network of marineprotected areas. Environmental Management, v. 52, p. 1341-54, 2013. doi: 10.1007/s00267-013-0174-x.

Mani-Peres, C.; Xavier, L.Y.; Santos, C.R. \& Turra, A. Stakeholders perceptions of local environmental changes as a tool for impact assessment in coastal zones. Ocean $\mathcal{E}$ Coastal Management, v. 119, p. 135-145, 2016. doi: 10.1016/j.ocecoaman.2015.10.005.

Mercado, L.Y. \& Lassoire, J. Assessing ourists' preferences for recreational and environmental management programs central to the sustainable development of a tourism area in the Dominican Republic. Environment development and sustainability, v. 4, p. 253-278, 2002. doi: $10.1023 /$ A:1021188701673.

Mundet, L. \& Ribera, L. Characteristics of divers at a Spanish resort. Tourism Management, v. 22, p. 501-510, 2001. doi: 10.1016/S0261-5177(01)00016-4.

Padi. Estatísticas Mercado de Mergulho. 2011. Available in: http://www.padi.com/ scubadiving/about-padi/statistics/. Accessed in: $1^{\circ}$ Jul. 2015.

Peters, H. \& Hawkins, J.P. Access to marine parks: a comparative study in willingness to pay.Ocean E CoastalManagement,v.52,p.219-228,2009.doi:10.1016/j.ocecoaman.2008.12.001.

Pinheiro, H.T.; Rocha, L.A.; Macieira, R.M.; Carvalho-Filho, A.; Anderson, A.B.; Bender, M.G. \& Gasparini, J.L. South-western Atlantic reeffishes: zoogeographical patterns and ecological drivers reveal a secondary biodiversity centre in the Atlantic Ocean. Divers. Distrib., v. 24, p. 951-965, 2018.

Pires, N.M.; Garla, R.C. \& Carvalho, A.R. The economic role of sharks in a major ecotourism archipelago in the western South Atlantic. Marine Policy, v. 72, p. 31-39, 2016. doi: 10.1016/j. marpol.2016.06.016. 
Oliveira, J.A.P. Governmental responses to tourism development: three Brazilian case studies. Tourism Management, v. 24, p. 97-110, 2003. doi: 10.1016/S0261-5177(02)00046-8.

Rhormens, M.S.; Pedrini, A.G. \& Ghilardi-Lopes, N.P. Implementation feasibility of a marine ecotourism product on the reef environments of the marine protected area of Tinharé and Boipeba islands (Cairu, Bahia, Brazil). Ocean E Coastal Management, v. 139, p. 1-11, 2017. doi: 10.1016/j.ocecoaman.2017.01.022.

Rodrigues, L.C.; Bergh van den, J.C.; Loureiro, M.L.; Nunes, P.A. \& Rossi, S. The cost of mediterranean sea warming and acidification: a choice experiment among scuba divers at medes Islands, Spain. Environmental and Resource Economics, v. 63, n. 2, p. 289-311, 2016.

Sauermann, G.; Andrade Jr., J.S.; Maia, L.P.; Costa, U.M.S.; Araújo, A.D. \& Herrmann, H.J. Wind velocity and sand transport on a barchan dune. Geomorphology, v. 54, p. 245-255, 2003. doi: 10.1016/S0169555X(02)00359-8.

Schuhmann, C.H. Recreational SCUBA divers' willingness to pay for marine biodiversity in Barbados.J.EnvironmentalManagement,v.121,p.29-36,2013.doi:10.1016/j.jenvman.2013.02.019.

Shideler, G.S. \& Pierce, B. Recreational diver willingness to pay for goliath grouper encounters during the months of their spawning aggregation off eastern Florida, USA. Ocean E Coastal Management, v. 129, p. 36-43, 2016. doi: 10.1016/j.ocecoaman.2016.05.002.

Simon, T.; Pinheiro, H.T. \& Joyeux, J.C. Target fishes on artificial reefs: evidences of impacts over nearby natural environments. Science of the Total Environment, v. 409, p. 4579-4584, 2011.

Smith, K.R.; Scarpaci, C.; Scarr, M.J. \& Otway, N.M. Scuba diving tourism with critically endangered grey nurse sharks (Carcharias taurus) off eastern Australia: tourist demographics, shark behaviour and diver compliance. Tourism Management, v. 45, p. 211-225, 2014. doi: 10.1016/j.tourman.2014.05.002.

Soares, M.O.; Paiva, C.C.; Freitas, J.E.P. \& Lotufo, T.M.C. Gestão de unidades de conservação marinhas: o caso do Parque Estadual Marinho da Pedra da Risca do Meio, NE - Brasil. J. Integrated Coastal Management, v. 11, p. 257-268, 2011. Available in: http://dx.doi.org/10. $5894 /$ rgci261.

Soares, M.O.; Rossi, S.; Martins, F.A.S. \& Carneiro, P.B.C. The forgotten reefs: benthic assemblage coverage on a sandstone reef (Tropical South-western Atlantic). Journal of the Marine Biological Association of the United Kingdom, v. 97, n. 8, p. 1585-1592, 2017. https:// doi.org/10.1017/S0025315416000965.

Sudarmadi, S.; Suzuki, S.; Kawada, T.; Netti, H.; Soemantri, S. \& Tugaswati, A.T. A survey of perception, knowledge, awareness and attitude in regard to environmental problems in a sample of two different social groups in Jakarta, Indonesia. Environment Development and Sustainability, v. 3, p. 169-183, 2001.

Tang, J.; Folmer, H. \& Xue, J. Estimation of awareness and perception of water scarcity among farmers in the Guanzhong Plain, China, by means of a structural equation model. JournalofEnvironmentalManagement, v.126,p.55-62,2013.doi:10.1016/j.jenvman.2013.03.051.

Teixeira, C.E.P. \& Machado, G.T. On the temporal variability of the sea surface temperature on the Tropical Southwest Atlantic Continental Shelf. Journal of Coastal Research, v. 2, p. 2071-2076, 2013. doi: 10.2112/SI65-350.1.

Tonin, S. \& Lucaroni, G. Understanding social knowledge, attitudes, and perceptions towards marine biodiversity: the case of tegnùe in Italy. Ocean $\mathcal{E}$ Coastal Management, v. 140, p. 68-78, 2017. doi: 10.1016/j.ocecoaman.2017.02.019. 
Tsoar, H.; Levin, N.; Porat, N.; Maia, L.P.; Herrmann, H.J.; Tatumi, S.H. \& Claudino-Sales, $\mathrm{V}$. The effect of climate change on the mobility and stability of coastal sand dunes in Ceará State (NE Brazil). Quaternary Research, v.71, p. 217-226, 2009. doi:10.1016/j.yqres.2008.12.001.

Uyarra, M.C.; Watkinson, A.R. \& Côté, I.M. Managing dive tourism for the sustainable use of coral reefs: validating diver perceptions of attractive site features. Environmental Management, v. 43, p. 1-16, 2009. doi: 10.1007/s00267-008-9198-z.

Wegner, E.; Tonioli, F.C. \& Cabral, D.Q. Underwater trails: a new possibility of marine tourism. Journal of Coastal Research, p. 990-993, 2006.

Worachananant, S.; Carter, R.W.; Hockings, M. \& Reopanichkul, P. Managing the impacts of SCUBA divers on Thailand's Coral Reefs. Journal of Sustainable Tourism, v. 16, p. 645, 2008. doi: $10.2167 /$ jost771.0.

\section{Supplementary material}

Supplementary Material I. Diving sites in Fortaleza, Brazil.

Supplementary Material II. Diving sites in Marine Protected Area Pedra da Risca do Meio, Brazil.

Supplementary Material III. Questionnaire: recreational diving in Fortaleza, Brazil. 